формування національної системи безпеки в межах кіберпростору. Окрім того, поява нормативно-правових механізмів впливу дозволить сформувати базовий захист для зменшення кіберконфліктів та прямих політичних атак, наслідки яких відшкодовують, на теперішній час, пересічні громадяни. Для більш поглибленого вивчення атак потрібно формувати новітні методи, які допоможуть захистити інформаційні системи окремих сфер та сформують стабільний захист та попередять потужні агресорські напади в інформаційному просторі.

\title{
Література:
}

1. Tkachenko, O., \& Tkachenko, K. (2018). Кіберпростір i кібербезпека: проблеми, перспективи, технології. Цифрова платформа: інформаційні технології в соціокультурній сфері, (1), 75-86. https://doi.org/10.31866/2617-796x.1.2018.147257

2. Фурашев, В.М., 2012. Кіберпростір та інформаційний простір, кібербезпека та інформаційна безпека: сутність, визначення, відмінності.Інформація і право,2(5), С. 162-175.

3. Баранов,О.А., 2014. Про тлумачення та визначення поняття «кібербезпека», Правова інформатика, 2(42), С. 54-62.

4. Дубов Д.В. Кіберпростір як новий вимір геополітичного суперництва : монографія / Д.В. Дубов. - К. : НІСД, 2014. - 328 с.

\section{DOI https://doi.org/10.30525/978-9934-26-120-6-14}

\section{УКРАЇНСЬКО-УГОРСЬКІ ВІДНОСИНИ В КОНТЕКСТІ РОСІЙСЬКОЇ АГРЕСІЇ: СУЧАСНИЙ СТАН}

\author{
Івлсва С. C. \\ студентка II курсу факультету міжнародних відносин, суспільних \\ комунікацій та регіональних студій \\ Національний університет «Львівська політехніка» \\ Науковий керівник - Лемко Ю. Р. \\ асистент кафедри політології та міжнародних відносин \\ Інститут гуманітарних та соиіальних наук Національного \\ університету «Львівська політехніка» \\ м. Львів, Украӥна
}

Угорщина $є$ не лише близьким сусідом України але й стратегічним партнером на міжнародній арені. Проте, попри дружні двосторонні 
відносини за опитуванням Ради зовнішньої політики «Українська призма» [1] щодо міжнародної політики України, Угорщина є другою після Російської Федерації «недружньою» країною в контексті взаємовідносин між двома країнами. Цьому передувало ряд чинників. Перш за все варто наголосити, що загальновідомим $\epsilon$ факт агресії Російської Федерації проти України, що триває вже понад сім років. Протягом цього часу Угорщина неодноразово підтримувала дії Російської Федерації та дипломатичним шляхом заперечувала критику в її бік, коли більшість світової спільноти виказувала підтримку Україні та впроваджувала санкції проти Росії. Вирішальним фактором в цьому було також напруження відносин між Україною та Угорщиною, наприклад, щодо прав та свобод угорської меншини на території України чи критика Закону України «Про освіту». Тому, на нашу думку, є доцільним та актуальним питання стану українсько-угорських відносин через неоднозначну позицію угорської сторони щодо порушення територіальної цілісності України та розгляд перспективи подальшого розвитку двосторонніх відносин в контексті російської агресії на 2021 рік.

Для кращого розуміння мотивів та дій Угорщини щодо російського конфлікту, варто дослідити ії відносини як з Україною як «жертвою агресора», так 3 самою державою-агресором, а отже Російською Федерацією.

Надзвичайно важливо $\epsilon$ розуміння того, що Угорщина $\epsilon$ інструментом РФ, за допомогою якого вона намагається впливати на політику $\mathrm{CC}$, а чинний прем'єр-міністр Угорщини Віктор Орбан є прихильником тісної співпраці між Росією та Угорщиною. Наведемо ряд причин такої співпраці. Перш за все Угорщина є залежною від Росії в банківській сфері, енергетиці та металургії. Дані держави тісно співпрацюють на міжгалузевому та регіональному рівнях. Окрім цього, Росія $\epsilon$ найбільшим торговельним партнером Угорщини поза $€$, a російська вакцина «Спутник V» була першою в $\mathrm{CC}$ схвалена в Угорщині, зокрема велися переговори щодо вироблення вакцини на іiі території. Для активної підтримки позиції РФ Угорщина виступає проти санкцій, наводить дані щодо втрат, які принесуть санкції як для Угорщини, так для $Є С$ в цілому.

Але не все так однозначно. 3 іншої сторони, Угорщина активно підтримує політику СС щодо санкцій, застосовує обмеження щодо РФ й виказує підтримку Мінському формату, зазначаючи, що зняття санкцій можливе лише за виконання Мінських домовленостей, а також, зазначимо, що саме Угорщина надала Україні статусу партнера НАTO 3 розширеними можливостями у червні 2020 року. Ті заходи, 
що ЄС здійснює проти Російської Федерації критикуються Угорщиною, проте схвалюються в загальному порядку з усіма країнами-членами.

Українсько-угорські відносини погіршилися через ухвалення Закону України «Про освіту» осінню 2017 року. Саме тоді Угорщина почала блокувати засідання (наприклад, Комісії Україна-НАТО) та робити заяви щодо порушення прав угорської меншини на території України.

Наприкінці 2020 року Дмитро Кулеба у своїй заяві зазначив, що 2021 року відносини з Угорщиною [2] є одним з фокусів зовнішньої політики України, оскільки угорська сторона $є$ готовою до конструктивного діалогу.

Визначальною подією 2021 року можна назвати зміну першого варіанту офіційної заяви Вишеградської четвірки щодо російської таємної операції в Чехії [4]. В4 затвердили ії 26 квітня 2021 року, але в короткому варіанті, оскільки Віктор Орбан не прийняв версію заяви, де вимагалося скасування проєкту «Північний потік-2», а також виказувалась підтримка Білорусі та Україні. Це ще раз $є$ доказом того факту, що Угорщина лавірує між своїми інтересами, інтересами РФ, СС та об'єднань, в які входить, та не готова до чітких та жорстких дій, спрямованих на завдання шкоди Російській Федерації.

Зустріч між представниками Угорщини та України відбулась 13 травня 2021 року в рамках візиту міністра закордонних справ України Дмитра Кулеби до Братислави, де вони обговорили належні справи та дійшли до того, що обидві сторони готові йти на компроміс та поступки.

Але вже 21 червня 2021 року Петер Сійярто, міністр закордонних справ Угорщини, на дебатах в ПАРС заявив, що існування сайту «Миротворець»є проблемою, що начебто «це список ворогів, які мають бути покарані». Нагадуємо, що він і сам $є$ в списку «Миротворець», але за його заявами його захистить контртерористична служба Угорщини, проте українцям та тим, хто мешкає на українській території $\epsilon$ причина боятися. Цим висловлюванням він ще раз підтверджує своє ставлення щодо дій України в рамках національної безпеки та наче їх анулює.

Досліджуючи політику Російської Федерації, можемо зазначити про вигідність послаблення українсько-угорські відносини, таким чином дана країна користується кожним моментом, аби створити в них напругу. Їй вигідно, аби угорська сторона діяла в зовнішньополітичних інтересах РФ, аби здійснювати свій вплив в межах цієї країни та на регіональному рівні.

Підсумовуючи вищесказане, вважаємо, що в цьому році спостерігається позитивна динаміка українсько-угорських відносин. Україна все ж $є$ для Угорщини шляхом для забезпечення підтримки 58 
угорської меншини на території України, а також ринком на експорт, розвитком співпраці в безпековому секторі. Проте, прогнозування щодо наших відносин є неоднозначним, оскільки тут впливає багато факторів. Перший з них - російський вплив на іiі зовнішню політику. Хоча Угорщина є та позиціонує себе як незалежна та вільна держава, іiі дії спрямовані на підтримку свого напряму політики, але не можна не помітити російського втручання та проросійського бачення, приклади якого наведені вище. Другий з важливих - співпраця безпосередньо України та Угорщини. Тільки двосторонні поступки та взаємодія допоможуть вийти 3 кризи та налагодити позитивні та дружні відносини між обома країнами.

\title{
Література:
}

1. Сергій Герасимчук. Які держави вважають «дружніми», а які ні, та чи остаточно Україна відвернулася від Росії? Украӥнська призма. 2021. URL: http://prismua.org/09-01-2021-2/.

2. Потіха А. Українсько-угорські відносини в контексті візиту глави МЗС Угорщини. Україна: подіï, факти, коментарі. 2021. № 2. C. 4-11. URL: http://nbuviap.gov.ua/images/ukraine/2021/ukr2.pdf.

3. Глава МЗС Угорщини поскаржився у ПАРС на український «Миротворець». Украӥнська правда. 2021. URL: https://www.pravda.com.ua/news/2021/06/21/7297969/.

4. Юрій Братюк. Угорщина заблокувала заяву Вишеградської групи 3 критикою агресії РФ. ZAXID.NET. 2021. URL: https://zaxid.net/ ugorshhina_zablokuvala_zayavu_vishegradskoyi_grupi_z_kritikoyu_rosiysk oyi_agresiyi_n1518064.

\section{DOI https://doi.org/10.30525/978-9934-26-120-6-15}

\section{ЗБРОЙНІ КОНФЛІКТИ ЯК КРИЗА СВІТОВОЇ КОМУНІКАЦЇ̈}

\author{
Лікарчук Д. С. \\ кандидат політичних наук, \\ дочент кафедри міжнародних відносин \\ Київський начіональний університет культури і мистецтв \\ м. Київ, Украӥна
}

Динаміка сучасних міжнародних відносин, нові модернізаційні процеси та глобальні виклики сучасного світу потребують нового осмислення поняття «збройні конфлікти». Відповідно до останніх 